\title{
Transmission of Kêlèntangan Music among the Dayak Bênuaq of East Kalimantan of Indonesia
}

\author{
Eli Irawati \\ Ethnomusicology Department, Faculty of Performing Arts, \\ Institut Seni Indonesia Yogyakarta \\ Jln. Parangtritis Km. 6,5 Sewon, Bantul, DI Yogyakarta, Indonesia, 55188 \\ e-mail: eliirawati3@gmail.com \\ DOI: https://doi.org/10.37134/mjm.vol8.7.2019
}

Published online: 15 December 2019

Cite this article (APA): Irawati, E. (2019). A Transmission of Kêlèntangan Music among the Dayak Bênuaq of

East Kalimantan in Indonesia. Malaysian Journal of Music, 8, 108-121.

https://doi.org/10.37134/mjm.vol8.7.2019

\begin{abstract}
Musical transmission is integral to the sustainability of musical traditions. Most literature on musical transmission focuses how songs are memorised rather than how instrumental pieces are transmitted. This study explores the transmission processes of the kêlèntangan, the instrumental pieces that accompany the Dayak Bênuaq rituals. The transmission processes comprise the conveyor, content and mechanism. There are three figures involved in this conveyor processesthe pênu'ung (musician), the pêngampir (observer) and pêmêliatn (shaman). I argue that transmission of kêlèntangan involves a triangular interaction among these three figures. In addition, the transmission of kêlèntangan generates two kinds of content-musical and non-musical, which requires different mechanisms. These mechanisms include bêkajiq (listening), kintau (imitating), to tameh (improvisation). The interaction between the pênu'ung transmits musical and nonmusical contents; while the interaction between the pêngampir and pênu'ung; pêmêliatn and pênu'ung; and pêmêliatn and pêngampir; each transmits non-musical content.
\end{abstract}

Keywords: content, conveyor, interaction, kêlèntangan, mechanism

\section{Background}

The transmission of music is an important aspect of the continuity of a musical practice, especially in today 's global world, where an exchange of cultural elements were common and, among other things, results in the uniformity of cultural practices across the world. Comprehensive studies on the oral transmission of music, so far, have paid more attention to music that uses lyrics, or often called songs, and there is a lack of detailed discussions on the oral transmission of instrumental pieces (Berger, 2005; Lord, 1971, 1991; Maloy, 2010; Rubin, 1995). It is assumed that the way to learn songs is different from learning instrumental music.

Kêlèntangan is a genre of instrumental music performed by the Dayak Bênuaq used in a wide variety of contexts compared to other types of music. This genre still exists to this day, so it is assumed that it is still has an important social function in the life of its people. This study aims to examine the transmission of kêlèntangan, the process of transmission among the Bênuaq Dayak people is related to bodily behaviour, and the transmission is related to the continuity of the kêlèntangan. It is important to obtain a more extensive insight of the transmission of music among the Bênuaq people. Due to its close relation to other activities, primarily ritual ceremonies, it is useful to look at the pêmêliatn (shaman), who leads the ritual, and this person's 
connection to the kêlèntangan performed in the context. Pênu'ung (musician) has to observe the pêmêliatn carefully, primarily at his gestures or physical behaviour, in order to perform it in accordance to the custom. The teaching and learning process of kêlèntangan does not occur in a specific setting that is deliberately intended for its transmission from one person to another, from masters to the novices. It's teaching and learning process takes place when kêlèntangan is performed. Thus, studying the transmission of kêlèntangan means examining its presence in rituals.

\section{Theoretical Framework}

Ethnomusicologist Shelemay (2008) defines the transmission of music as "communication of musical materials from one person to another, whether in oral, aural, or written forms, without regard to the time depth of the materials transmitted" (p. 154). In brief, transmission can be defined as a transfer of knowledge or skills from one individual or group to another. In ethnomusicology, the process of teaching and learning of music is commonly referred to as transmission and acquisition (Campbell \& Higgins, 2015, p. 651). This concept of transmission among others shows that there are three components in this process, namely the conveyor, content, and mechanism (Schönpflug, 2009, pp. 4-6). The mechanism becomes the most prominent element here, as it covers how the conveyor transmits the content.

With regards to the mechanism of transmission, Lord (1971) points out that there are three stages in the acquisition of knowledge or learning in oral tradition. The first is when a novice listens, they become familiar with the traditions he/she studies. The second stage is the process of imitation and assimilation (e.g. reciting). The third stage is what Lord (1991) calls 'singing for a critical observers.' Each of these stages certainly includes specific techniques: how a novice memorises the sound material he or she listens to, and then imitates, to be able to develop his/her performance (p. 21).

In the oral tradition, whereby there is no musical notation, a mnemonic device known as 'formula' is used. The function of the formula proposed by Lord (1971) is not to help remember, but as a frame of reference for spontaneously presenting matter. Nevertheless, the different composition is not spontaneously arranged during the performance, but there is already a repertoire (p. 35). So, what is needed is a frame of reference for remembering, not composing. The mnemonic device for remembering the commonly used music material is 'chunking', which is in view of the composition in smaller or shorter units, such as motifs. The material that has been possessed is continuously trained, that is, following the performances, so that a penu'ung becomes proficient and can create differences in various contexts, ranging from profane to sacred. The ability of this pênu'ung will later be transmitted to other pênu'ung in the future. This cycle, among others, sustains the continuity of kelentangan music. However, the role of society is also important, because those who provide the context for the practice of contradiction, and society's expectations are the aesthetic frameworks for the music presentation.

In summary, the theoretical framework constructed to examine the problem in this study is as follows: The transmission element consists of three elements, namely the conveyor, the content, and the mechanism. Different musicians transmit different contents, in a certain way. Thus, it is necessary to examine what kinds of conveyors are involved in the transmission of opposition, so that the content and the mechanism can be understood.

\section{Literature Review}

Hand (2017) discusses five approaches to learning and transferring knowledge practiced by traditional performing arts artists in Central Java, namely gamelan musicians, dalang (master puppeteer), and dancers including learning by ear, simulating simultaneously, practicing and doing, exposure and absorption, and learning in groups/associations. She states that the traditional way of learning in the performing arts directly enables one to gain knowledge of various kinds of art at once in a learning process (p. 29).

Chan and Ross (2015) conducted a non-interventive ethnographic observation of the transmission of music by the Semai musicians of Malaysia. Local musicians, who are key players in the community, are placed in the role of a teacher. Findings show that teacher-student mobility, freedom of choice, intuitive responses, 
integration of cultural concepts, flexibility and adaptability are the approaches used by the Semai musician in responding to the children's learning culture. This paper further states that teachers need to consider cultural nuances and differences in music experience when designing their music curriculum and assessment approaches to music education. Furthermore, it emphasises on the flexibility and adaptability of teachers to actively build and reconstruct their teaching approaches by accessing children's musical understanding, talents and competencies from various cultural backgrounds (p. 691).

Brinner (1999) describes how "a Javanese musician must listen interpretively and respond appropriately to particular cues" (p. 24). Brinner (1995) defines listening interpretively as a process of deductive imitation, which "involves idiomatic translation or transformation of an essence abstracted from perceptual input" (p. 138). In other words, the musicians follow instruments that may be played different than their own, using the heterophonic structure of the music to play together. He describes how the gamelan ensemble forms an interactive safety net, allowing musicians to follow along without creating problems for the overall music of the ensemble (pp. 179-180).

Utomo and Febri (2017) state that the oral tradition plays a role in becoming a medium of social science education in the Gunungpati Semarang community in Central Java. Important findings in this study are that oral traditions have benefit to social science education in society but because humans may be educated and should get education early, wherever they are. The Gunungpati people still feel the benefits of oral traditions in the process of transmitting social values which function for entertainment, education, remembering the past (learning history), solidarity and togetherness, social control, the function of protest and social criticism, and finally religious function (p. 169).

The difference between this research and the above literature is that music transmission occurs in the context of rituals. It explains the factors that support the transmission processes, as well as the relationship between transmission and continuity of interest. This study examines the relationship between three interrelated elements, namely the conveyor, content and mechanism in the ritual context. The author views the performers not only as pênu'ung (musician), but also as pèngampir (observer) and pêmêliatn (shaman). Analysis of the interaction between these different actors shows that two types of content are transmitted, namely musical content and non-musical content. The next consequence is that two different types of content give rise to different mechanisms or stages of transmission.

\section{Methodology}

Instead of including only the pênu'ung (musician) as transmission conveyor, I added the pèngampir (observer) and pêmêliatn (shaman) as well to this category. According to Lono Simatupang (personal communication, 5 June 2016), pèngampir can be regarded also as actors in a performance for their acknowledgement and involvement play a role in determining the success or failure of performances. Secondly, Nawan (personal communication, 1 June 2016) said that all pèngampir, or those who attend a ritual, have the potential to become pênu'ung. Third, the pèngampir are an inseparable aspect of a ritual. The organisers of the ritual, and anyone involved in it, are also at the same time pèngampir who can participate.

Analysis of the interaction among these three roles shows the presence of two types of contents, i.e. musical and non-musical contents. These two different types of contents are then explored so that they can be understood in terms of how they are transmitted.

The methodology for this research included literature review, interviews, participant observer, documentation and analysis. This research also used the ethnographic approach whereby I experienced the how cultural practices in society influence the learning, transmission and importance of kêlèntangan music to society.

\section{Transmission Processes}

The transmission of music involves at least three components, namely the conveyer, content (what is taught or studied) and the mechanism (Schönpflug, 2009, pp. 4-6). In the following section, I describe these three roles in detail. 


\section{Conveyor}

Kêlèntangan can be performed among others due to its conveyors or actors. In this study, I include the pênu'ung (musician), pêngampir (observer), and pêmêliatn (shaman) in the category of conveyor or actor. There are no special requirements or conditions to become a pênu'ung. Although most of pênu'ung acquire their skill to play kêlèntangan from the elders who are family-related (e.g. grandparents and father), this is not a condition to becoming a pênu'ung. The fact that the pênu'ung comes from a family of musicians demonstrates the family's importance in the transmission processes of kêlèntangan practices. The title of pênu'ung is not ascribed, but is achieved. Thus, this status is more cultural than genetic. Much effort is required to obtain this status,

The conveyor refers to the person or actor that becomes the source of the information being transmitted (Schönpflug, 2009, pp. 4-5). Nevertheless, the presence of the public, the community that supports the performance - the pêngampir cannot be separated from the existence of kêlèntangan. The public, in this case, does not really act as 'observers' in the sense of enjoying a performance for merely aesthetic purposes as the kêlèntangan is not a performance for entertainment but it is performed as an accompaniment to a ritual or nonritual activity (e.g. gantar, a social dance).

The third transmission conveyor leads the procession of the bêlian ritual. During bêlian sêntiu (shamanism ceremony) or bêlian bawo (healing ceremony), the pêmêliatn becomes the reference for the pênu'ung. What, how, and when the kêlèntangan pieces are performed depends on the pêmêliatn. Therefore, those who play kêlèntangan in rituals not only have to master the skill of playing instruments, but also to have knowledge about the ritual. That is why the chief of the kêlèntangan ensemble, who usually plays the kêlèntangan instrument and sulikng dewa, the most senior pênu'ung, knows the rituals that they accompany very well.

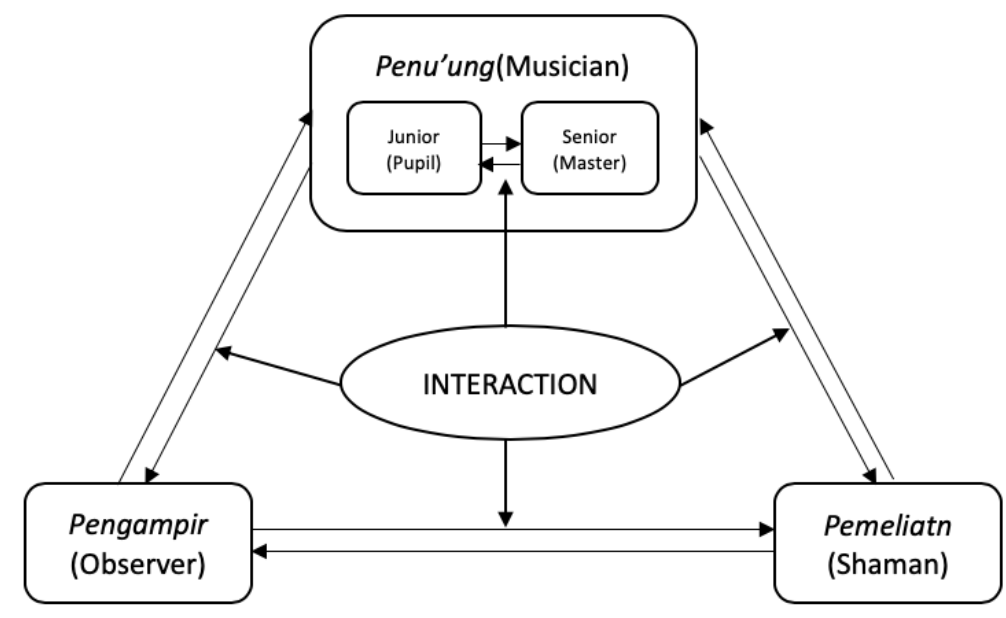

Figure 1. The conveyors of the transmission of kêlèntangan and their interaction (Source: Irawati, 2016).

The three conveyors of transmission described above are inter-related to each other. First, the interaction between pênu'ung pupil and pênu'ung master shows how novice musicians learn musical skills from their masters. They watch and listen to the music. In other words, its content is mostly musical. The second interaction is between pênu'ung and pêngampir, which potentially generates a new pênu'ung. Pèngampir attending a ritual involving kêlèntangan performance get exposure to the music. Bênuaq children who attend rituals unwittingly memorise what they see, hear, and feel. Finally, for various reasons, they begin to internalise how kêlèntangan is performed. In turn, the pèngampir become an evaluator for kêlèntangan performance. The evaluator constructs an image of what is kêlèntangan and how it should be. A regeneration of pênu'ung occurs, as well as the pèngampir. 
Third, the interaction between the pêngampir and pêmêliatn does not consciously occur but it still exists. Just as pêngampir becomes parties who establish the standard of how kêlèntangan should be, the pengampir constructs the standard of how rituals, which include a procession led by pêmêliatn, should be performed. On the one hand, pêmeliatn leads the rituals, which, among others, means actualising the customs of Dayak Bênuaq that have been passed down for generations so that the community, i.e. pèngampir, can perceive it in this case. On the other hand, the pêngampir becomes a kind of evaluator to the pêmêliatn: what he performs and presents of the kêlèntangan. Pêmêliatn leads the procession, performs movements and gestures, and chants, and is in turn observed by the pêngampir who memorises it from their experience, which becomes the standard to the 'proper ritual, proper action, proper performance.' In future, this experience will become the benchmark for the community when they watch a pêmêliatn perform in a similar ritual. Of course, the same benchmark applies for the same case. For example, one cannot assess the action of pêmêliatn in the bêlian sêntiu based on, or in reference, to the action of the pêmêliatn in kwangkay. In addition, the relationship between pêmêliatn and the pêngampir is that the pengampir provide the contexts for the ritual. Thus, indirectly, the existence of pêmêliatn is also supported and valued by the pêngampir.

The fourth is the interaction between pênu'ung and pêmêliatn. Pêmêliatn is an important figure related to pênu'ung in the ritual ceremonies such as bêlian bawo (healing ceremony), bêlian sêntiu (shamanism ceremony), and kwangkay (funeral music). Performing kêlèntangan in a ritual is not merely about how to beat the instruments and produce good sounds but also how the pieces performed by penu'ungs correspond to the passages of the ritual and the pêmêliatn's will who leads it. If novice or junior pênu'ungs acquire their knowledge and skills primarily from their master or senior pênu'ung, then they acquire their knowledge about the rituals especially from pêmêliatn. Since kêlèntangan performance is closely tied to the context, it is very important for pênu'ung to have knowledge about it. Therefore, it is not a surprise that pênu'ung who learns to play kêlèntangan also learns about rituals.

Table 1

Interaction and Relationship between Pênu'ung, Pêngampir, and Pêmêliatn

\begin{tabular}{|c|c|c|c|}
\hline $\begin{array}{l}\text { Transmission } \\
\text { Conveyors }\end{array}$ & $\begin{array}{l}\text { Pênu'ung } \\
\text { (Musician) }\end{array}$ & $\begin{array}{l}\text { Pêngampir } \\
\text { (Observer) }\end{array}$ & $\begin{array}{l}\text { Pêmêliatn } \\
\text { (Shaman) }\end{array}$ \\
\hline Pênu'ung & $\begin{array}{l}\text { Knowledge and skill to play } \\
\text { the instrument for various } \\
\text { occasions. }\end{array}$ & $\begin{array}{c}\text { Pênu'ung transmits } \\
\text { kêlèntangan musical pieces to } \\
\text { the pêngampir. }\end{array}$ & $\begin{array}{c}\text { Pênu'ung plays } \\
\text { kêlèntangan according to } \\
\text { pêmêliatn in a ritual. This is } \\
\text { then recorded by pênu'ung and } \\
\text { becomes a reference to a } \\
\text { similar ritual in the future. }\end{array}$ \\
\hline Pêngampir & $\begin{array}{l}\text { The pêngampir evaluate the } \\
\text { kêlèntangan and also provide } \\
\text { the context for kêlèntangan } \\
\text { performance as well } \\
\text { as pênu'ung. }\end{array}$ & (not focused on in this study) & $\begin{array}{l}\text { Pêngampir provide context for } \\
\text { the rituals that involved } \\
\text { pêmêliatn that involved } \\
\text { including customs, processions } \\
\text { and various rules. }\end{array}$ \\
\hline Pêmêliatn & $\begin{array}{l}\text { Pêmêliatn transmits the rules of } \\
\text { a ritual to the pênu'ung. }\end{array}$ & $\begin{array}{c}\text { Pêmêliatn transmits knowledge } \\
\text { by actualising customs, so that } \\
\text { it can be seen and experienced } \\
\text { by the pêngampir. }\end{array}$ & (not focused on in this study) \\
\hline
\end{tabular}

Based on the examination of the conveyors in the transmission of kelèntangan, it appears that there are two types of material or content to be transmitted, i.e. the musical material and non-musical. 


\section{Transmission Content}

There are two types of content or material in the transmission of kêlèntangan, musical and non-musical. Musical content is mainly transmitted from pênu'ung senior to the junior, or a master to a novice, as well as from pênu'ung to the pêngampir, while the non-musical content is transmitted mainly from pêmêliatn to the pêngampir and pêmêliatn to the pênu'ung.

The major musical content to be transmitted is the composition or the musical piece is the sound produced by the instruments in the ensemble. There is no song title used specifically to refer to kêlentangan pieces. The pieces are usually named according to its accompanying activity, for example kêlèntangan gantar, a piece played to accompany the gantar dance; kêlèntangan bêlian sentiu, the accompaniment of bêlian sêntiu, etc. The pieces or compositions of kêlèntangan also contain certain rules or convention acknowledged-but implicitly_among the pênu'ung and Dayak Bênuaq people as a theory of music.

Kêlèntangan piece in bêlian bawo, bêlian sêntiu, and kwangkay is not played continuously from the beginning of the ritual to the end. Instead, it is played to follow the stages of ritual and instruction of the pêmêliatn. Besides the composition or piece, another musical content to be transmitted from the master pênu'ung to the novice is the technique of playing instruments. Such techniques, in turn, will actualise the piece of kêlèntangan.

In addition to musical content, there are also non-musical contents in the transmission of kêlèntangan. The most important non-musical content is the sequences of ritual, mainly transmitted between the pêmêliatn and the pênu'ung. Performing kêlèntangan in ritual contexts or for ritual purposes cannot be done without considering the sequences of its ritual, including the pêmêliatn's instructions. The following example illustrates the point.

Table 2 shows that a pênu'ung does not only deal with the skills of playing the instruments in the kêlèntangan ensemble, but must have sufficient knowledge in the ritual custom Bênuaq in general. Based on the description of the transmission conveyors, it seems that there are two types of transmission content, i.e. musical and non-musical. Consequently, there are different mechanisms or ways to transmit different contents by different conveyors. The following examines the transmission mechanism to transmit different kinds of content.

Table 2

Ritual sequences and kêlèntangan in bêlian bawo and bêlian sêntiu

\begin{tabular}{|c|c|c|}
\hline Rituals & Stage & Kêlèntangan and other accompaniment \\
\hline Bêlian Bawo & Ngawat & $\begin{array}{l}\text { The narere begins with the sepui blown three times by the pêmêliatn. } \\
\text { The Pêmêliatn sings the bêmemang bejajuruq la mo } \\
\text { The kêlèntangan is played monotonously. } \\
\text { Before reaching puncutn jaa jatus, the pêmêliatn must go through several places, } \\
\text { namely Pantiq PapaLongan, } \\
\text { Nawang Langit, and Bawo Langit. } \\
\text { Each time arriving at one of these places, the pêmêliatn pauses to request for permission. } \\
\text { Each arrival is marked by the pausing of the kêlèntangan in seconds, then } \\
\text { the pêmêliatn reads incantation. }\end{array}$ \\
\hline $\begin{array}{l}\text { Bêlian } \\
\text { Sêntiu }\end{array}$ & Ngawat & $\begin{array}{l}\text { The Pêmêliatn sings bêmemang as the basis of the other parts. The kêlèntangan is not } \\
\text { yet sounded, while the players are preparing themselves. } \\
\text { Each pêmêliatn alternately blows sepui three times, starting from the leader of } \\
\text { bêlians or guruq, and then is alternately followed by his prajiq or pupil. } \\
\text { Next, the leader of pêmêliatns sings bêmemang, followed by the entire pêmêliatn, men } \\
\text { and women, with melody, rhythm and words that exactly match to those of the leader's. } \\
\text { After the bêmemang is completed, the pêmêliatn stands and moves his feet instructions to } \\
\text { the pênu'ung to immediately play the instruments. At first, the kêlèntangan } \\
\text { instrument players, as leaders, play a melody requested by the pêmêliatn which is shortly } \\
\text { thereafter followed by the gimar and genikng players. }\end{array}$ \\
\hline
\end{tabular}


After the music is played in less than half an hour with monotonous melodic patterns, tempo, and rhythm, by instruction of the pêmêliatn, the kêlèntangan pauses.

The Guruq bêlian sings bêmemang which is not followed by the prajiq.

A moment later, the kêlèntangan plays the same melody and tempo as previously. The pêmêliatn concentrates while holding awir batu raja, accompanied by the kêlèntangan. The pêmêliatn sings the bêmemang to drive away evil spirits. The pêmêliatn slowly starts to move his body to spin, and the kêlèntangan is played continuously according to the pêmêliatn's body movements.

In the next sequence, bejajaruq la mo, the pêmêliatn stands under awir batu raja while holding a hanging cloth and singing the bememang, preparing to fly with the smoke of the incense. At this time, the accompaniment sounds monotonous in a relatively moderate tempo. At this stage, the kêlèntangan is played in a relatively long duration but with monotonous melody and patterns.

Having considered enough, the pêmêliatn asked the pênu'ung to stop playing kêlèntangan for a moment, replaced by sulikng dewa and gimar.

In each checkpoint on the way to jaa puncutn jatus, the kêlèntangan also stops. When kêlèntangan stops playing, the pêmêliatn sings bêmemang. Once completed, the kêlèntangan is played again.

Having reached puncutn jaa jatus, the pêmeliatn sings the bêmemang again. The pêmêliatn goes back down from puncutn, jaa jatus together with the spirits of the ancestors. The kêlèntangan is played with a constant tempo.

After the ghosts and the spirits of the ancestors are believed to arrive at the human world and to eat the offering that has been served, they are treated to a dance attended by all the pêmêliatn, both men and women, moving around the awir batu raja. Usually, the dancers are holding the ancestor's skull on their back. To accompany the dance, the kêlèntangan is played loudly and excitedly, but still adjusted to the movements of the pêmêliatn.

At the bakawat stage, the kêlentangan is played with a bit of improvisation on its melodic pattern spontaneously. Its tempo is the medium, which is increasingly faster according to the pêmeliatn's movement.

At the nyenteyau stage, the pêmêliatn, accompanied by the kêlèntangan, also sings the bêmemang.

At the stage of ngasi ngado, the kêlèntangan is played with a bit slow and softly but dynamic tempo compared to that played in the bakawat.

After a while, the guruq bêlian asked the pênu'ung to stop, because the bêmemang will be sung again. After the bêmemang is sung, the kêlèntangan is sounded again.

At the tangai stage, the pêmêliatn sings the last bêmemang, and according to the pêmêliatn's instruction, kêlèntangan is played in a moderate tempo as the accompaniment. The last bêmemang is sung as a sign that the bêlian sêntiu has been completed.

After the last bêmemang is sung, the kêlèntangan is played as at the narere stage, with a fast and dynamic tempo, according to the pêmêliatn's movement.

\section{Transmission Mechanism}

The knowledge, beliefs, norms, arts of this culture of the Dayak Bênuaq are transmitted orally. There are no institutions set up intentionally for learning purposes. Their tradition is passed down from one generation to the next, from one member of society to another implicitly in various daily occasions, including in the case of kelèntangan practice. The transmission content includes both musical and non-musical contents. How is the content transmitted and received by the conveyors in the transmission of kêlentangan? According to Lord (1971), there are three stages in the acquisition of knowledge or learning in oral tradition. The stages proposed are parallel to the learning process proposed by Ki Hadjar Dewantara, namely niteni (means listening, watching), nirokake (imitating), and nambahi (improvising/replicating) (Suroso, 2011, p. 51). Among the Dayak Bênuaq people, this process is respectively called bêkajiq, kintau, and tameh. The following section examines each stage in the transmission process of kêlèntangan in relation to both musical and non-musical contents. 


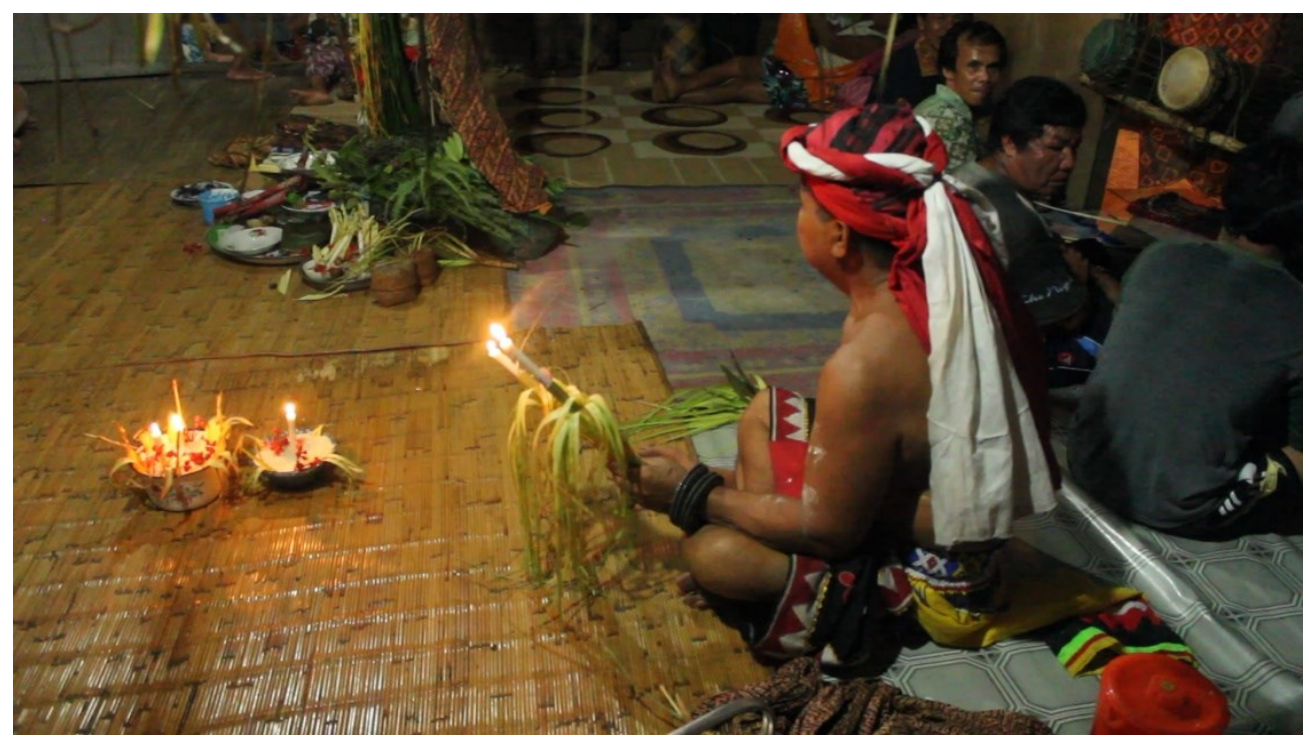

Figure 2. A pêmêliatn performs the bêlian bawo ritual, and the gimar players appear in the right side background (Source: photo by Irawati, 2015)

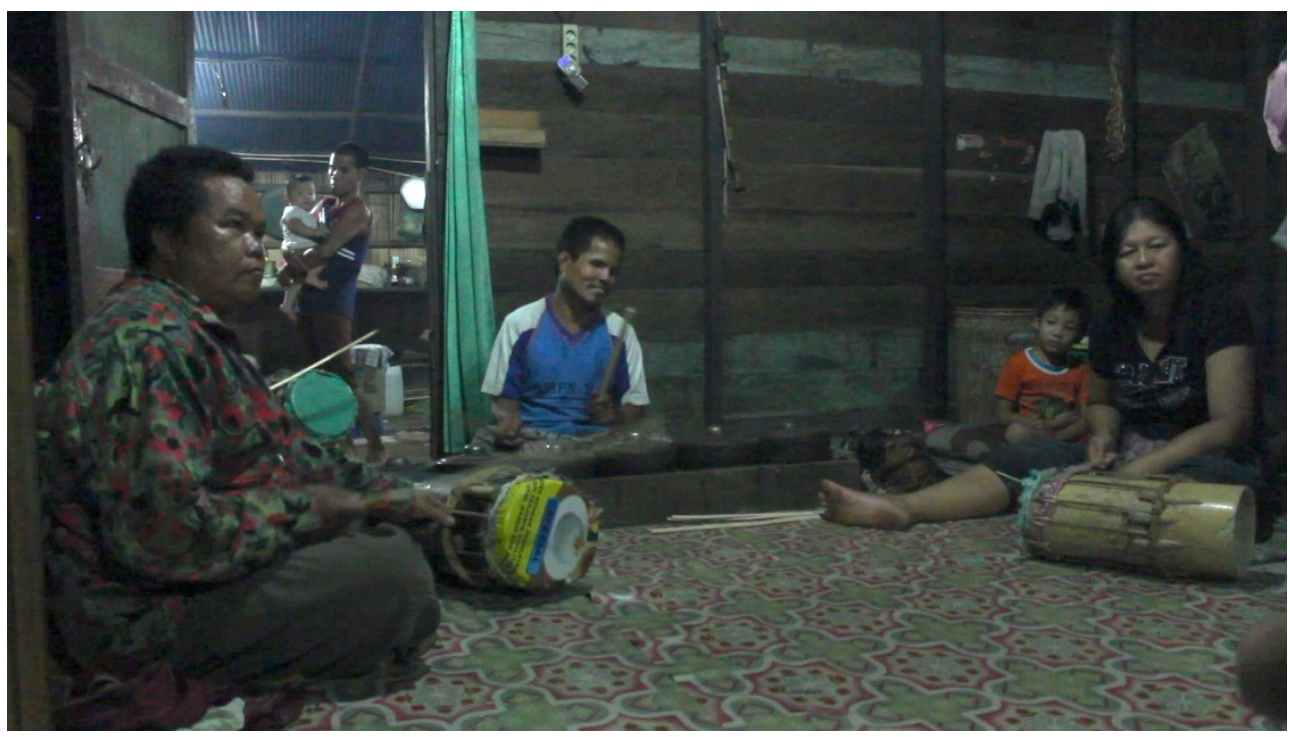

Figure 3. An informal setting of learning music in the Dayak Bênuaq people of East Kalimantan (Source: photo by Irawati, 2015)

The first stage is bêkajiq, a term in Bênuaq language, which means listening, or watching carefully. The term has similar meaning to the word in Indonesian, 'kaji', means investigating and studying that involve the mind (Research Team, 2008, p. 618). Listening or watching implies the existence of certain impetus to focus on a particular object so that there is certain information to memorise. The stage of listening in the transmission process occurs in various occasions, particularly in the performance of kêlèntangan in lamin for various ritual activities, in a series of activities such as gantar dance, feasts, etc. People who are interested to learn to play kêlèntangan, called pupils, come to the event and notice how kêlèntangan is performed by the pênu'ung who has already mastered the techniques. Interaction between teacher-pupil or externalisation-internalisation process occurs. There is no coercion from both sides - teacher and pupil - to carry out this externalisation or internalisation process. 
Generally, the most attractive instrument to learn in the ensemble is the kêlèntangan, a horizontal small gong chime. This is not surprising due to the fact that the instrument is the most prominent in terms of musical function and plating techniques compared to other instruments in the ensemble. In certain occasions, such as when performing kêlèntangan to accompany gantar dance during a celebration, a student can directly participate and play the instruments. It could be the first instrument being played that is not complicated, such gênikng. However, the reality may not always be the case. At this stage, it does not only involve a listening action, but also imitating.

As mentioned above, a musical fact does not consist of the sonorous (auditory) aspect alone, but also visual and kinesthetic. That is, ways to learn kêlèntangan was not limited to just listening (capturing auditory phenomena), but also involves capturing the visual and kinesthetic phenomena.

Sound Aspect. So far, the sound may be the only aspect regarded as a musical fact. Nevertheless, it should be realised that the sound comes as a result of physical activity, such as plucking the strings with the hand, beating a xylophone key or even playing one's own limbs, blowing the air, and so on.

Bêkajiq, listening to the sonorous aspect of kêlentangan, means capturing and memorising the sounds of music. Therefore, it requires a reproduction of recorded and remembered materials that have been listened to. As mentioned above, there are two types of content transmitted - and thus be remembered - by someone who wants to be a pênu'ung, that is the composition or piece of kêlèntangan as well the playing techniques that produce the sounds to the order and rules of kelèntangan performed during an activity, especially a ritual.

In his study of the transmission of the gusle epic singer-player in Yugoslavia, Lord (1991) stated that the formula is an important element for the singer to compose while performing poetry. This is because his object of study was poetry that was composed and performed at the same time. The formula became a frame of reference that helps singers in composing the materials. This is in contrast to the performance of kêlentangan. Although both live and are transmitted in oral culture, the two have quite different characteristics. First, the Yugoslav epic poetry composed by singer-performer is actually composed while being performed, but its frame and materials have already existed. One who wants to be an epic singer studies and internalises the 'frame' (formulas) and materials (words) that are used to compose the song-poems. Lord (1991), as cited in Badrun (2014), argued that the formula is very useful for performers, which becomes the guide in the process of composition

Someone who wants to be an epic singer must study and internalise the frames (i.e. formula) and materials (e.g. words) that are used to compose the song poems. Lord (1991), as quoted in Badrun (2014), argued that the formula is very useful for presenters, which becomes a guide in the process of composition and generating formula to the poet ( p. 20). Meanwhile, the composition or piece of kêlèntangan already exists and it is not composed-borrowing Nettl's (2015) term-in the course of performance (p. 60). There is already a certain composition played for a particular activity. If there are variations in the composition of kêlentangan, it is only the improvisation or development that would be allowed by Bênuaq people. Second, kêlèntangan is closely tied to the context, does not stand for its sake, and is an integral part of the activity being accompanied, while singing in the Yugoslavian epic is presented for the performance purposes only.

If formulas, in the oral transmission of the Yugoslavian epic, have a very important role as a reference for the presentation of a song, then the reference in the performance of kêlentangan is the ritual sequences (Moder, personal communication, 27 July 2015) This is mainly because the composition to be played is already there to follow the sequences of the ritual. The pênu'ung must perform the kêlèntangan according to the ritual led by the pêmêliatn. In the transmission process of the Yugoslavian epic song, a prospective performer mainly listens and internalisesthe formulas and words as a reference and its materials. In the transmission of kêlèntangan, a pupil listens to and internalises the rules of rituals or other activities that provide the context of performance as well as the composition or piece of kêlèntangan itself. How does the pupil listen to and internalise the materials?

Based on the transcription of kêlèntangan pieces in bêlian, bêlian sêntiu, and kwangkay, it appears that the musical content that must be listened to and internalised by pênu'ung is not too long. 
1

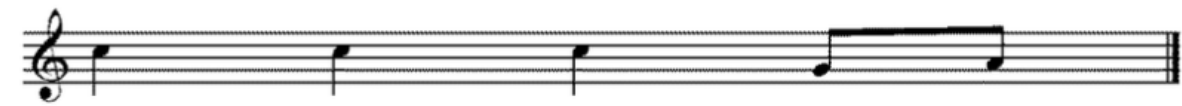

2

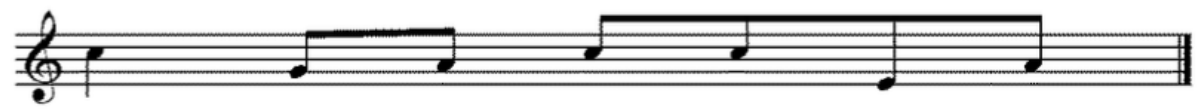

3

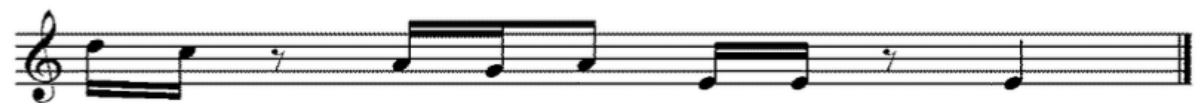

4

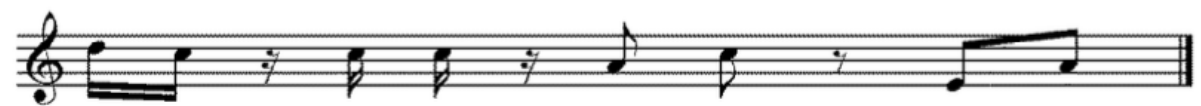

Figure 4. Motives played on kêlèntangan for bêlian bawo (healing ceremony of the Dayak Bênuaq)

Transcriptions above show that there are four basic patterns in the accompaniment of belian bawo. Two patterns are played only once, at the beginning, and two patterns are played throughout the piece. The variation arises due to the notes value.

1

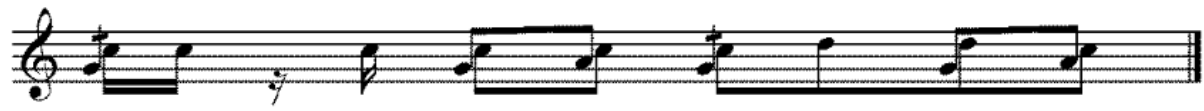

2

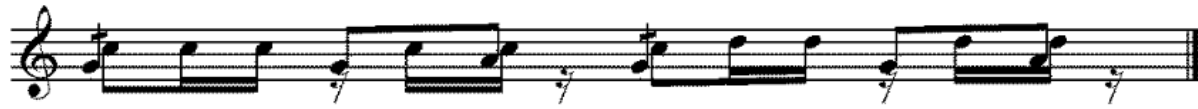

Figure 5. Motives played on kêlèntangan for bêlian sêntiu (shamanism ceremony)

Based on the transcription of basic patterns above, it appears that there are two main patterns being played throughout the piece. Changes in tempo and dynamics occur by way of ritual led by the pêmeliatn.
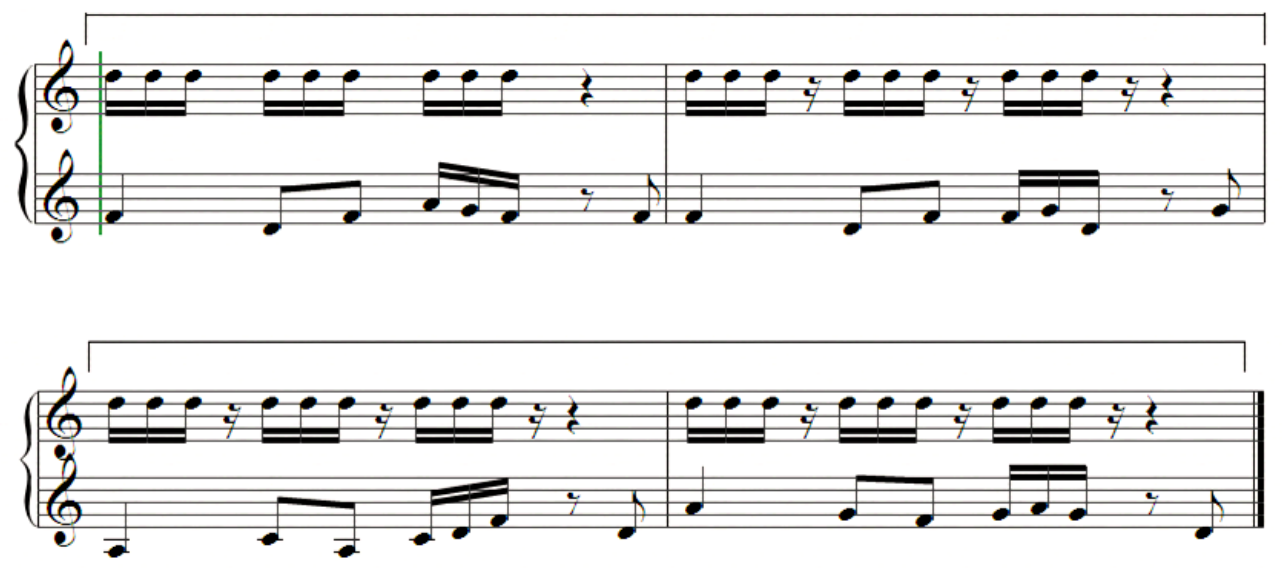

Figure 6. Motives played on kêlèntangan for kwangkay.

Based on the examination of the patterns of melody in the pieces of kêlèntangan played in bêlian bawo, bêlian sêntiu, and kwangkay, it can be said that all of them have relatively short patterns, phrases, sentences, which is not so difficult to memorise. Kêlèntangan was performed according to the ritual, not vice versa. Therefore, the sequence of a ritual, bêlian bawo for example, is a framework for kêlentangan performed in it. For the musicians, probably the most complicated part of bêkajiq has not been about memorising melodies or 
patterns on musical instruments, but rather how to keep their music in line with the instructions or movements of pêmeliatn who leads the ritual. To become a master, a pênu'ung must have immense exposure to it. Once the skills and knowledge required to be a pênu'ung has been mastered, one can begin to get involved actively in the performance of kêlèntangan (Irawati, 2016, p. 68).

Bêkajiq is the learning process of kêlèntangan including non-musical content, obtained by a pênu'ung when he attends the performance in various occasions rather than in a specific setting intended for teaching and learning, and without explicit communication process of teaching and learning. In addition to the prospective musician, transmission also occurs between the pêngampir and pênu'ung. Pêngampir are those who attend the events, and who consciously or unconsciously memorise and internalise the technical skill of the music, rules and sequences of the ritual, as well as the whole customs of their culture. However, not all of the pèngampir pay a particular attention to the kêlèntangan. Those who are interested will direct their attention to the ensemble.

Visual and Kinesthetic Aspects. Visual and kinesthetic aspects are two different things of the musical facts, but in the case of kêlentangan, both are two inseparable aspects. Visual and kinesthetic aspects of the kêlèntangan performance could be divided into two, namely musical content and non-musical content. The following will be discussed one by one.

Watching Visual and Kinesthetic Aspects of Musical Content. As mentioned above, the sound produced by the kelentangan is the result of a physical activity. Thus, in order to learn the playing techniques of kêlèntangan and other instruments, it is not only necessary to listen to the sound, but one must also observe the bodily movements of the pêmêliatn.

In contrast to the learning process in the Balinese gamelan for example, which has at least two instruments of each type in an ensemble so that the instrument can be used by teachers while the students imitate, in the kelèntangan ensemble there is only one instrument of each type. As a result, the visual and kinesthetic aspects that has been observed and cannot necessarily be imitated by the instrument, although sometimes the musician imitates them by beating his bare hands on his own limbs. A pupil who already has enough skill and knowledge can estimate the speed of the tempo by watching how fast the musician 's first hand swings when hitting the instrument. This is because the speed of the swinging arm is closely related to the tempo of the piece to be played. Nevertheless, in the kêlentangan performance in a ritual, the tempo depends on the ritual stages and the pêmêliatn's instructions.

The height at which the player raises his hand to beat the instruments must be considered to determine the dynamics of a piece. The higher the raised hand to hit the instrument, the louder the dynamics will be. Bodily gestures of the musicians are the materials that have to be listened by one who learns kelèntangan. For pênu'ung, visual experience becomes no less important in the bêkajiq because it is able to provide ways to memorise the materials. The pênu'ung, however, does not so much have gestures used as the sign. Gestures as a cue are primarily acted by pêmêliatn, the leader of the ritual.

Watching Visual and Kinesthetic Aspects of Non-musical Content. Visual and kinesthetic aspects of non-musical content that is listened to by a pênu'ung are mainly pêmêliatn's bodily movements as the leader of the ritual. Pêmêliatn's gestures and actions are important aspects that must be considered by a pênu'ung as a cue for their playing - when to start playing the instrument, how loud or soft to play the dynamics, how fast or slow to beat the tempo, etc. Pêmêliatn does not give an instruction verbally while he is leading the ritual. The pêmêliatn's bodily behaviours are the signs that must be considered by the pênu'ung.

The next stage in the learning process is the kintau, which means imitation. Sometimes the stages of bêkajiq and kintau cannot be separated because both stages coincide with each other. A novice pênu'ung who is in a bêkajiq stage can directly participate in the ensemble, imitating the playing on the instruments he has seen before. Usually, the instrument played by a novice or pupil is the simple one such as gênikng or gimar. Imitating the musical patterns in certain rituals implies that the candidate penu'ung practices how to perform kêlèntangan on a particular activity. This is because the moment when the pupil is in the kintau stage of learning is the actual performing context. Learning does not occur in a special setting, but in a real and natural one. Thus, the kintau stage in the transmission of kêlèntangan is mainly how a pênu'ung deals with musical material. Pêngampir and pêmêliatn can be said to be passive in this stage, because kintau emphasises more on the technical-practical aspects, i.e. imitating playing techniques. This is different from those of bêkajiq, which occurs both in the pêngampir and pênu'ung. 
Table 3

Pêmêliatn's bodily movements and its relation to the kêlèntangan

\begin{tabular}{|c|c|}
\hline $\begin{array}{l}\text { Bodily movements or } \\
\text { gestures of pêmêliatn }\end{array}$ & Kêlèntangan \\
\hline Splashing water & $\begin{array}{l}\text { Slowing down the tempo, splashing the water is believed to be an act of releasing evil } \\
\text { spirits; sometimes he also sings the bememang. }\end{array}$ \\
\hline Stomping his feet & $\begin{array}{l}\text { Tempo tends to be irregular, following the movements of pêmêliatn; or } \\
\text { transition of kêlèntangan to the sulikng dewa or to bêmemang; or } \\
\text { transition to the next stage. }\end{array}$ \\
\hline Stomping his arms & $\begin{array}{l}\text { The tempo of the piece is the same as the arms movement. This gesture among others } \\
\text { describes the exorcism. }\end{array}$ \\
\hline Spinning the body & Kêlèntangan is played in a fast tempo \\
\hline Turned his head & Pênu'ung makes a mistake in playing kêlèntangan. \\
\hline
\end{tabular}

Once a pupil is able to imitate the playing techniques and 'to feel' the pieces, he usually adds a bit of improvisation on the patterns but not an extreme one. This is called tamèh. This results in a kind of variation patterns. An example is in the accompaniment of bêlian bawo and bêlian sêntiu. Kêlèntangan played in this ritual shows that there are basic patterns, variations of the basic patterns.

Based on the transcription of the kêlèntangan in bêlian bawo, bêlian sêntiu, and kwangkay, the variation patterns are formed by note values. It does not change significantly in the overall composition of kêlèntangan. Meanwhile, the variations in dynamics and tempo depend on the pêmêliatn's instructions.

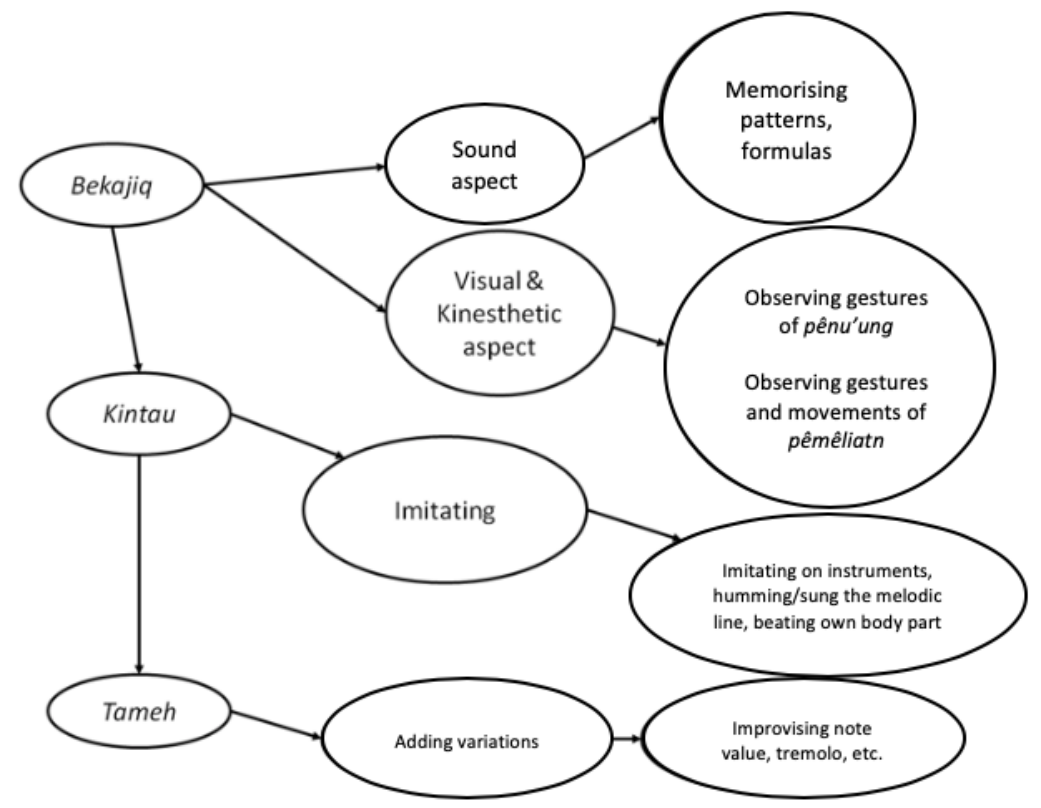

Figure 7. Three stages of learning process in the transmission of kêlèntangan (Source: Irawati, 2016)

This study shows that the transmission of music is not limited to the transfer of knowledge and skills that lead to the emergence of a new musician only. The transmission is not about how a musician learns a certain material, then performing it, as shown by Lord (1991). This study shows the following:

First, if the transmission conveyor is not only limited to the musicians who perform, then the transmission is no longer only about the transference of knowledge and practical-musical skills. Second, if the transmission conveyor is not only limited to the musicians who perform, consequently, the relationship between these actors vary. Thus, the material or content transmitted are also different. In this study, the different 
transmission conveyors result in different musical and non-musical contents. The non-musical material emerges because the transmission conveyors are not musicians only. Third, the implication that arises from different conveyors and contents is a somewhat different mechanism. The interaction between pênu'ungs transmits musical knowledge and skills in bêkajiq, kintau, and tameh. This is in contrast to the interaction between pêmêliatn and pênu'ung, pênu'ung and the pêngampir, as well as pêmêliatn and the pêngampir. Fourth, the context becomes an important part for the music that is closely tied with its context. Bêlian bawo and bêlian sêntiu, for example, are the reference or framework to perform kêlèntangan. As a result, pênu'ung has to get relevant knowledge and understanding of the ritual. This means that in the transmission, pênu'ung is required to acquire not only the musical knowledge and skills, but also knowledge about surrounding activities of the music.

Based on these facts, it can be summarised the process of music transmission does not only involve musicians, but also other non-musician actors. If the conveyor of transmission involves more than one type (for example, not only musician, but also the observer), then the relationship between the actors should be examined because the interaction between different types of conveyors will result in different types of content. In turn, the different types of content will lead to the emergence of different transmission mechanisms. Furthermore, we also have to consider the activities surrounding a musical practice, whether it is related to the performance. If so, the performer and musicians also need to acquire the skills and knowledge of those activities. In short, the performer should also acquire non-musical knowledge.

\section{Conclusion}

In conclusion, kêlèntangan is still transmitted among the Dayak Bênuaq people because the activities involving the kêlèntangan are still practiced by the people. Kêlèntangan is closely tied to its context, such as bêlian bawo and bêlian sêntiu. The Bênuaq people still conduct rituals in their lives as one way to meet their needs in the face of life. The preservation of these rituals, in turn, provides the opportunity for the transmission of kêlèntangan. Second, the transmission process of kêlèntangan can be seen by examining the interaction between the conveyor, the content and the transmission mechanism. Interactions between different conveyors result in transmitting different contents. Thus, to transmit different contents, a different mechanism is required. Transmitting music does not only deal with auditory aspects, but also visual and kinesthetic. Thus, teaching and learning, mainly in musical traditions of Indonesia as in this case, must consider various aspects of a musical occasion.

Last but not least, transmission is indeed an important part in the continuity of kêlentangan practice. However, transmission cannot stand-alone. The contexts and the activities of the profane and the sacred rituals that are still held by the Bênuaq people must support it. Thus, the continuity of kêlèntangan does not solely rely on the transmission, but also on the cultural ecosystem. Maintaining the continuity of kelèntangan means to keep the ecosystem of the Bênuaq culture.

\section{References}

Badrun, A. (2014). Patu Mbojo: Struktur, konsep pertunjukan, proses penciptaan, dan fungsi. Lengge: Mataram. Berger, A. M. B. (2005). Medieval music and the art of memory. Berkeley: University of California Press.

Brinner, B. (1995). Knowing music, making music: Javanese gamelan and the theory of musical competence and interaction. Chicago, IL: University of Chicago Press.

Brinner, B. (1999). Cognitive and interpersonal dimensions of listening in Javanese gamelan performance. The World of Music, 41 (1), 19-35.

Campbell, P. S. \& Higgins, L. (2015). Intersection between Ethnomusicology, music education, and community music. In S. Pettan \& J. T. Titon (Eds.), The Oxford handbook of Applied Ethnomusicology (pp. 639-668). New York, NY: Oxford University Press.

Hand, R. (2017). Approaches to learning traditional performing arts in central java through a direct encounter. Malaysian Journal of Music, 6 (2), 29-48.

Irawati, E. (2016). Aspek-aspek transmisi kelentangan dalam masyarakat Dayak Benuaq: Studi Etnomusikologis. Laporan Hasil Penelitian Hibah Disertasi Doktor. Yogyakarta: LPPM ISI Yogyakarta. 
Lord, A. B. (1971). The singer of tales. New York, NY: Antheneum.

Lord, A. B. (1991). Epic singers and oral tradition. Ithaca: Cornell University Press.

Maloy, R. (2010). Inside the offertory: Aspects of chronology and transmission. New York, NY: Oxford University Press.

Nettl, B. (2015). The study of Ethnomusicology: Thirty-three issues and concepts. Illinois: University of Illinois Press.

Rubin, D. C. (1995). Memory in oral traditions: The cognitive psychology of epic, ballads, and counting-out rhymes. New York, NY: Oxford University Press.

Schönpflug, U. (2009). Introduction to cultural transmission: Psychological, developmental, social, and methodological aspects. In U. Schönpflug, (Ed.), Cultural transmission: Psychological, developmental, social, and methodological aspects (pp. 1-8). Cambridge: Cambridge University Press.

Shelemay, K. K. (2008). Ethnomusicologist, ethnographic method, and the transmission of tradition. In G. F. Barz \& T. J. Cooley (Eds.). Shadows in the field: new perspectives for fieldwork in Ethnomusicology (pp. 141-155). New York, NY: Oxford University Press.

Chan, C. S. C. \& Ross, V. (2015). Preliminary Exploration of a Semai Musician's Transmission of Indigenous Musical Traditions in Peninsular Malaysia. Pertanika Journal of Social Sciences \& Humanities, 23 (3), 691-710.

Suroso. (2011). Pemikiran Ki Hadjar Dewantara tentang belajar dan pembelajaran. Scholaria, 1 (1), $46-72$.

Utomo, Cahyo Budi; Febri, Kurniawan Ganda. (2017). Bilamana tradisi lisan menjadi media pendidikan ilmu sosial di masyarakat Gunungpati. Harmony, 2 (2), 169-184.

\section{Biography}

Eli Irawati is a lecturer at the Ethnomusicology Department, Faculty of Performing Arts, Indonesian Institute of the Arts, Yogyakarta, and local-traditional music of Kalimantan, Indonesia, is her focus of study and teaching. Her MA and PhD degree was obtained at Gadjah Mada University, Yogyakarta. Research interest includes issues of music transmission, ritual, identity, nationalism, tourism, globalisation and modernisation in Indonesia. 